\title{
SUCCESS OF PROFESSIONAL ORIENTATION OF DEAF PEOPLE ACCORDING TO CHOSEN OCCUPATION AND EMPLOYMENT
}

Admira Beha ${ }^{1}$

Review paper

DOI: $10.21554 / \mathrm{hrr} .041710$

Faculty of Education and Rehabilitation Sciences, University of Tuzla

Received: 18.01.2017

Accepted: 10.03.2017

\begin{abstract}
This paper presents a comparative overview of selected professions of deaf people and people with no hearing impairments within their professional orientation and occupations carried out in their workplace. The research was conducted on a sample of 238 respondents. For the evaluation of the results, descriptive analysis was used. The results showed that deaf people in $36.6 \%$ of cases are not employed in the occupation for which they have acquired professional qualifications, compared to $14.5 \%$ percent of respondents with no hearing impairments. The results indicate that it is necessary to reorganize the inefficient process of professional orientation of the deaf people, which should contribute to establishing an efficient system of employment in professions for which they are oriented.
\end{abstract}

Key words: professional orientation, career choice, deaf workers and workers without hearing impairments.

\section{INTRODUCTION}

Deaf people belong to a very heterogeneous population, which in addition to hearing impairment usually have additional psychological and physical disorders. Hearing impairment in addition to communication difficulties leaves greater effects on the functioning of the deaf people. Although no differences in capabilities required to perform the duties and tasks in different areas were determined, there is an issue of their employment within the profession for which they are qualified. The cause of this situation can be found in the inadequate professional orientation and career choices for deaf people. With professional orientation, those people are directed to those occupations that are best suited to individual differences and abilities, specific mental and physical demands of the workplace and educational programs of individual schools.
Bujas (1968) states that the essence of the professional orientation is contained in individual psycho-physical characteristics and preferences, different requirements at workplaces in terms of abilities, skills and knowledge. The same author states that performing more poorly at a job does not mean the overall professional unfitness, but the causes can be found in a bad choice of occupation. A significant number of young deaf people and people with hearing impairment receive additional services in the context of social disability insurance (Daněk and Busby, 1999), without being involved in any production activities (Bullis et al., 1995; Bullis et al., 1997). DeCaro et al (2001) suggest that deafness can be a cultural determinant when it comes to career choice and opportunities for deaf people.

\footnotetext{
${ }^{1}$ Correspodence to:

Admira Beha, Faculty of Education and Rehabilitation Sciences, University of Tuzla

Ul. Univerzitetska 1, 75000 Tuzla, B\&H

Phone: 0038761869816

E-mail: admirabeha@gmail.com
} 
These authors have observed that regardless of the cultural differences between countries, deaf people are directed in similar occupations based on the attitudes of employers and society, and Punch et al (2004) stated that when conducting evaluations for the choice of profession, there is a tendency of ignoring the quality of individual personality, and generally only the hearing impairment is taken into account. Communication requirements at workplace: communication in silence and noise, detection of the sound source, localization of sounds, distinguishing different sounds, very often not taken into account when choosing a profession. Although Schroedel and Geyer (2000) state that a deaf person can perform duties and tasks as successfully as their colleagues with normal hearing, if they are provided with equal educational opportunities and equal access to employment, their years of education to overcome interest, which are not in accordance with the labor market. Lane et al (1996) stated that the adoption of the Law on Professional Rehabilitation removed obstacles to hiring deaf people in government institutions, as well as in large corporations, which contributed to the extension of legislation to the private sector and allowed the expansion of the list of professions for which deaf people had been trained. There is no legislation that limits the deaf people in certain occupations, which indicates the presence of equal opportunities in access and choice of acquiring professional qualifications. Although the professional orientation is an activity that has a long tradition in the context of rehabilitation of deaf population, there were observed no positive and affirmative results, which can be linked with an adequate choice of profession and employment. Results of the research conducted by Schroedel (1992), in which teachers and counselors evaluated the ability of making decisions about the choice of profession of deaf students, which showed that that $61 \%$ of students considered to have insufficient knowledge of particular industries and that $40 \%$ of them are not aware of their professional skills and interest for performing certain occupations. Gottshall and Stefanou (2011) stated that deaf students may have difficulties in understanding their own abilities in finding a job, but that does not mean that experts should take over the decision on the choice of profession, because in this way a sense of helplessness and inability to making decisions is developing. According to research conducted by Jambor and Elliott
(2005) the cause of the incorrect view about the possibility of carrying out certain professions for deaf people may be information provided during adolescence by teachers, parents and guardians, who believe that deafness prevents an individual to engage in certain occupations and to be successful in them. Bonds (2003) stated that deaf people face difficulties in finding and keeping a job, because of inadequate training in the context of professional rehabilitation, which could be overcome with adequate education and professional training, while research conducted in the US and Australia revealed that students with hearing impairment and deaf students in regular schools were included in very few activities for planning their career choice (Punch et al., 2006; Luft and Huff, 2011; Luft, 2014). Lent et al (2000) examined the influence of social factors on the choice of occupations of deaf population, where they found that discrimination and inadequate support of the system plays an important role in career guidance and professional development of deaf people.

The influence of parents in professional orientation of deaf children is extremely important. Experience shows that parents of deaf children often do not have enough information when it comes to choice of occupation and jobs their children can perform. Since deaf children in $90 \%$ of cases have hearing parents, who usually had no previous experience or knowledge about deafness, DeCarlo et al (1983) stated that parents very often express low expectations about the professional development of their deaf children, and as the reasons for this they point out difficulties in communication and safety at the workplace. Schroedel and Carnahan (1991) came to similar findings, which stated that parents of deaf children believe that deafness limits their ability to work, and that deaf children cannot participate equally in the workplace as their peers with no hearing impairment, and also Jamieson et al (2011) stated that parents of deaf children express concern and uncertainty in educational and professional opportunities of their children. Research conducted by Weisel and Cinamon (2005) points out that parents of deaf children express low expectations toward abilities of deaf people to achieve success in carrying out various occupations. In this way, as stated by DeCaro et al (2001), the interests of deaf individuals, their intellectual abilities, and their personality traits, which are taken into account in the guidance hearing population are ignored. 
Professional orientation is usually planned and implemented by persons with no hearing impairments, which by Benedict and Sass-Lehrer (2007) control the direction of education of deaf people and have a strong influence on legislative policy, research programs, curriculum, and the work of institutions engaged in professional rehabilitation.

\section{METHODS OF WORK}

The study sample consisted of 238 subjects, aged between 18 and 65 years, divided into two subsample. The first subsample consisted of deaf subjects ( $\mathrm{n}=$ 124) who have a minimum of one year of experience in tasks they performed, and the other subsample consisted of subjects without hearing impairment (n $=114$ ), having at least one year of experience with deaf people. The study was conducted in public and private companies in which respondents had a work contract.

For data processing descriptive analysis method was used, using computer statistical program SPSS for WINDOWS 14.

\section{Descriptive characteristics of the research sample}

The sample of deaf workers consisted of $65.3 \%$ of male respondents and $34.7 \%$ of female respondents. The largest percentage of deaf people $(35.5 \%)$ was born in the period from 1961 to 1970 , which were between 47 and 56 years, followed by respondents born from 1971 to 1980 (33.1\%) which were 37 to 46 years, and respondents born from 1981 to 1991 (18.5\%), which were between 26 and 36 years. The lowest percentage of respondents were born between
1951 and $1960(8.1 \%)$ and had 57 to 66 years, and respondents born between 1991 and 1995 (4.8\%) which were between 22 and 26 years. Respondents covered by this research are employed in the field of craft services and manufacturing $(71.6 \%)$, in the service sector are present in $18.8 \%$ of cases, in the context of health care institutions $(6.3 \%)$, in the mining and construction $(2.4 \%)$ and education $(0.8 \%)$. The highest percentage of respondents have completed secondary education $(93.5 \%)$, followed by respondents with a university degree (4\%) and low-skilled workers in $2.4 \%$ of cases.

The sample of workers and foremen with no hearing impairment included $56.8 \%$ male and $43.2 \%$ of female respondents. The largest percentage of respondents (37.8\%) was born in the period from 1961 to 1970 , followed by respondents born from 1971 to 1980 (29.7\%), from 1981 to 1990 (18\%), from 1951 to $1960(13.5 \%)$ and the lowest percentage of respondents born from 1991 to 1995 (0.9\%). Frequency of representation of workers without hearing impairment by age ranges from 22 years to 66 years of age, and the highest percentage of respondents were between 37 and 54 years (67.5\%). The structure of the sample of employees and manager without hearing impairment consisted of respondents employed in the field of craft services and manufacturing $(55.8 \%)$, service sector $(12.5 \%)$, health care institutions $(14.2 \%)$, mining and construction $(11.7 \%)$ and education $(5.8 \%)$. The analyzed data on the qualifications of workers show that respondents without hearing impairment in $82.9 \%$ of cases have secondary education, and a university degree in $11.7 \%$ of cases. The study also included $5.4 \%$ of respondents without education.

Table 1. Structure of subsample of deaf workers in relation to gender, age, experience and qualifications

\begin{tabular}{|c|c|c|c|c|c|}
\hline \multirow[t]{2}{*}{ Variable } & & \multicolumn{2}{|c|}{$\begin{array}{l}\text { The amount of deaf } \\
\text { respondents }\end{array}$} & \multicolumn{2}{|c|}{$\begin{array}{l}\text { The amount of } \\
\text { respondents without } \\
\text { hearing impairment }\end{array}$} \\
\hline & & f & $\%$ & f & $\%$ \\
\hline \multirow[t]{2}{*}{ Sex } & Male & 81 & 65,3 & 63 & 56,8 \\
\hline & Female & 43 & 34,7 & 48 & 43,2 \\
\hline \multirow[t]{5}{*}{ Year of birth } & $1951-1960$ & 10 & 8,1 & 15 & 13,5 \\
\hline & $1961-1970$ & 44 & 35,5 & 42 & 37,8 \\
\hline & $1971-1980$ & 41 & 33,1 & 33 & 29,7 \\
\hline & 1981-1990 & 23 & 18,5 & 20 & 18,0 \\
\hline & 1991-1995 & 6 & 4,8 & 1 & 0,9 \\
\hline \multirow{3}{*}{$\begin{array}{l}\text { Qualification of } \\
\text { respondents }\end{array}$} & Without education & 3 & 2,4 & 6 & 5,4 \\
\hline & Secondary education & 116 & 93,5 & 92 & 82,9 \\
\hline & University degree & 5 & 4,0 & 13 & 11,7 \\
\hline
\end{tabular}




\section{RESULTS AND DISCUSSION}

Table 2 shows the ratio of completed professional education of the deaf, their acquired qualifications and jobs in which they are employed. Examining these results, it can be concluded that the largest percentage of deaf people were educated to work as tailors $(16.1 \%)$, shoemakers $(9.7 \%)$, car painters $(8.9 \%)$, tinsmiths $(8.1)$ bookbinder $(7.3 \%)$, locksmiths $(6.5 \%)$ and sign maker $(6.5 \%)$. The same percentage $(3.2 \%)$ of deaf people were educated for therapists, hairdressers and mechanical technicians, followed by opticians, draftsmen and photographers $(2.4 \%)$, dental technicians and the audiologists $(1.6 \%)$. In a small percentage $(0.8 \%)$ respondents with secondary education have gained qualification for the professions of precise mechanics, metal grinders, upholsterers, economic, tourist and leather technicians, car electricians, graphic artists, plumbers, electricians, stamp-makers, jewelers, installers of central heating, web and product designers, and in the context of university degree they were educated for economists, social workers and construction engineers, each with a percentage of $0.8 \%$.

Also, to similar data come Boutin and Wilson (2009), which stated that persons with hearing impairment were educated and employed in the context of professional activities (art, education and managerial jobs), while deaf people were oriented to crafting professions (operators of the machinery, metal and wood processing, welders, sign maker, as well as jobs in the context of transporta- tion, preparation and processing of food, janitors, etc.), explaining this practice in a way that in the context of expert jobs a greater interaction with the hearing environment is expected, which requires greater communication skills.

Schildroth et al. (1991) presented data that $20 \%$ of deaf workers, after high school, were employed in jobs related to food preparation, $17 \%$ in jobs related to technical and office work, and $10 \%$ in housekeeper jobs. Research conducted by Capella (2003), which compared the effectiveness of professional rehabilitation of deaf persons and persons without hearing impairment, indicating that deaf people in $11.3 \%$ of cases were fewer employed in the context of expert and technical professions, and in $11.5 \%$ of cases over-represented within manufacturing jobs.

Examination of the data relating to the completed education for tailors, sign maker, physical therapists, dental technicians, metal grinders, electricians, stamp-makers, web designers, civil engineers and economists, it is recognized that deaf people are employed in workplaces, which are consistent with their achieved qualification. From a total of 33 professions for which deaf people were trained in the process of professional rehabilitation, at 10 of them deaf people are working within their acquired qualifications, indicating that in $69.7 \%$ of all professions skilled deaf people are not represented. The largest deviations in completed educations and jobs is reflected in jobs like shoemakers, tinsmiths, hairdressers, opticians and photographers. 
Table 2. Comparative display of completed educations and workplaces where employees are deaf respondents

\begin{tabular}{|c|c|c|c|c|c|c|}
\hline \multirow[t]{2}{*}{ Profession } & \multicolumn{2}{|c|}{ Completed education } & \multicolumn{2}{|c|}{ Workplace } & \multicolumn{2}{|c|}{$\begin{array}{l}\text { Working in their } \\
\text { profession }\end{array}$} \\
\hline & $\mathbf{f}$ & $\%$ & $\mathbf{f}$ & $\%$ & $\mathbf{f}$ & $\%$ \\
\hline Tailor & 20 & 16,1 & 22 & 17,7 & 20 & 16,1 \\
\hline Shoemaker & 12 & 9,7 & 7 & 5,6 & 7 & 5,6 \\
\hline Car painter & 11 & 8,9 & 8 & 6,5 & 8 & 6,4 \\
\hline Car tinsmith & 10 & 8,1 & 2 & 1,6 & 2 & 1,6 \\
\hline Bookbinder & 9 & 7,3 & 7 & 5,6 & 7 & 5,6 \\
\hline Locksmith & 8 & 6,5 & 6 & 4,8 & 6 & 4,8 \\
\hline Sign maker & 8 & 6,5 & 8 & 6,5 & 8 & 6,4 \\
\hline Physiotherapist & 4 & 3,2 & 4 & 3,2 & 4 & 3,3 \\
\hline Hairdresser & 4 & 3,2 & 0 & 0 & 0 & 0 \\
\hline Mechanical technician & 4 & 3,2 & 3 & 2,4 & 3 & 2,4 \\
\hline Optician & 3 & 2,4 & 0 & 0 & 0 & 0 \\
\hline Technical drawer & 3 & 2,4 & 2 & 1,6 & 2 & 1,6 \\
\hline Photographer & 3 & 2,4 & 0 & 0 & 0 & 0 \\
\hline Dental technician & 2 & 1,6 & 2 & 1,6 & 2 & 1,6 \\
\hline Audiologist & 2 & 1,6 & 1 & 0,8 & 1 & 0,8 \\
\hline Precise mechanic & 1 & 0,8 & 0 & 0 & 0 & 0 \\
\hline Upholsterer & 1 & 0,8 & 0 & 0 & 0 & 0 \\
\hline Metal grinder & 1 & 0,8 & 1 & 0,8 & 1 & 0,8 \\
\hline Economic technician & 1 & 0,8 & 0 & 0 & 0 & 0 \\
\hline Car electrician & 1 & 0,8 & 1 & 0,8 & 1 & 0,8 \\
\hline Leather technician & 1 & 0,8 & 0 & 0 & 0 & 0 \\
\hline Graphic artist & 1 & 0,8 & 0 & 0 & 0 & 0 \\
\hline Plumber & 1 & 0,8 & 0 & 0 & 0 & 0 \\
\hline Electrician & 1 & 0,8 & 0 & 0 & 0 & 0 \\
\hline Stamp-maker & 1 & 0,8 & 1 & 0,8 & 1 & 0,8 \\
\hline Jeweler & 1 & 0,8 & 0 & 0 & 0 & 0 \\
\hline Installer of central heating & 1 & 0,8 & 0 & 0 & 0 & 0 \\
\hline Economist & 1 & 0,8 & 1 & 0,8 & 1 & 0,8 \\
\hline Web designer & 1 & 0,8 & 1 & 0,8 & 1 & 0,8 \\
\hline Civil engineer & 1 & 0,8 & 1 & 0,8 & 1 & 0,8 \\
\hline Product designer & 1 & 0,8 & 0 & 0 & 0 & 0 \\
\hline Social worker & 1 & 0,8 & 0 & 0 & 0 & 0 \\
\hline Tourist technician & 1 & 0,8 & 0 & 0 & 0 & 0 \\
\hline Uneducated workers & 3 & 2,4 & 18 & 12,1 & 3 & 2,4 \\
\hline Total & 124 & 100 & 96 & 74,8 & 79 & 63,4 \\
\hline
\end{tabular}

Table 3 shows the ratio of completed educations for professions of people without hearing impairment, acquired qualifications and jobs in which they are employed. By examining the results it can be concluded that the highest percentage of persons without hearing impairment were qualified to professions like physiotherapists $(14.4 \%)$, tailors $(7.2 \%)$, graphic artists (7.2\%), mechanical technicians $(6.3 \%)$ and economic technicians $(5.4 \%)$.

The same percentage of respondents $(4.5 \%)$ were educated for professions of audiologists, electricians, and mining technicians, following by economic tech- nicians, carpenters and shoemakers $(3.6 \%)$, civil and electrical engineers and lawyers (2.7\%), as well as drivers , mechanics, administrative technicians and turners $(1.8 \%)$. In a smaller percentage of respondents $(0.9 \%)$ with secondary education have gained qualification for the professions of car painters, locksmiths, instrument technicians, electronic technicians, painters, ceramists, telecommunications technicians, gas system installers and plumbers, fashion designers, veterinary technicians, and within the university education economists, social workers, civil and electrical engineers and teachers each with a percentage of $0.9 \%$. 
The largest deviations in completed educations and jobs is reflected in the professions of tailors and mechanical technicians. From a total of 34 professions for which respondents without hearing impairments were educated in their professional rehabilitation, it was found that in all professions skilled workers were present. Looking at Table 3 it can be recognized that $84.5 \%$ of respondents without hearing impairment work in the workplace for which they have professional qualifications.

Table 3. Comparative display of completed education and jobs in which respondents without hearing impairment are employed

\begin{tabular}{|c|c|c|c|c|c|c|}
\hline \multirow[t]{2}{*}{ Profession } & \multicolumn{2}{|c|}{ Completed education } & \multicolumn{2}{|c|}{ Workplace } & \multicolumn{2}{|c|}{$\begin{array}{c}\text { Working in their } \\
\text { profession }\end{array}$} \\
\hline & $\mathbf{f}$ & $\%$ & $\mathbf{f}$ & $\%$ & f & $\%$ \\
\hline Physiotherapist & 16 & 14,4 & 16 & 14,4 & 16 & 14,4 \\
\hline Tailor & 8 & 7,2 & 12 & 10,8 & 8 & 7,2 \\
\hline Graphic artist & 8 & 7,2 & 7 & 6,3 & 7 & 6,3 \\
\hline Mechanical technician & 7 & 6,3 & 2 & 1,8 & 2 & 1,8 \\
\hline Economic technician & 6 & 5,4 & 5 & 4,5 & 5 & 4,5 \\
\hline Audiologist & 5 & 4,5 & 5 & 4,5 & 5 & 4,5 \\
\hline Electrician & 5 & 4,5 & 3 & 2,7 & 3 & 2,7 \\
\hline Mining technician & 5 & 4,5 & 5 & 4,5 & 5 & 4,5 \\
\hline Merchant & 4 & 3,6 & 2 & 1,8 & 2 & 1,8 \\
\hline Carpenter & 4 & 3,6 & 4 & 3,6 & 4 & 3,6 \\
\hline Shoemaker & 4 & 3,6 & 4 & 3,6 & 4 & 3,6 \\
\hline Construction technician & 3 & 2,7 & 3 & 2,7 & 3 & 2,7 \\
\hline Electrical technician & 3 & 2,7 & 3 & 2,7 & 3 & 2,7 \\
\hline Lawyer & 3 & 2,7 & 1 & 0,9 & 1 & 0,9 \\
\hline Driver & 2 & 1,8 & 2 & 1,8 & 2 & 1,8 \\
\hline Car mechanic & 2 & 1,8 & 1 & 0,9 & 1 & 0,9 \\
\hline Administrative worker & 2 & 1,8 & 2 & 1,8 & 2 & 1,8 \\
\hline Turner & 2 & 1,8 & 2 & 1,8 & 2 & 1,8 \\
\hline Plumber & 1 & 0,9 & 1 & 0,9 & 1 & 0,9 \\
\hline Car painter & 1 & 0,9 & 1 & 0,9 & 1 & 0,9 \\
\hline Civil engineer & 1 & 0,9 & 1 & 0,9 & 1 & 0,9 \\
\hline Social worker & 1 & 0,9 & 1 & 0,9 & 1 & 0,9 \\
\hline Locksmith & 1 & 0,9 & 1 & 0,9 & 1 & 0,9 \\
\hline Instrument technician & 1 & 0,9 & 1 & 0,9 & 1 & 0,9 \\
\hline Electronic technician & 1 & 0,9 & 1 & 0,9 & 1 & 0,9 \\
\hline Painter & 1 & 0,9 & 1 & 0,9 & 1 & 0,9 \\
\hline Ceramist & 1 & 0,9 & 1 & 0,9 & 1 & 0,9 \\
\hline Telecommunication technician & 1 & 0,9 & 1 & 0,9 & 1 & 0,9 \\
\hline Teacher & 1 & 0,9 & 1 & 0,9 & 1 & 0,9 \\
\hline Gas system installer & 1 & 0,9 & 0 & 0 & 1 & 0 \\
\hline Fashion designer & 1 & 0,9 & 0 & 0 & 0 & 0 \\
\hline Veterinary technician & 1 & 0,9 & 0 & 0 & 0 & 0 \\
\hline Economist & 1 & 0,9 & 1 & 0,9 & 1 & 0,9 \\
\hline Electrical engineer & 1 & 0,9 & 1 & 0,9 & 1 & 0,9 \\
\hline Uneducated workers & 6 & 5,4 & 9 & 8,1 & 6 & 5,3 \\
\hline Total & 111 & 100 & 101 & 91,6 & 95 & 84,5 \\
\hline
\end{tabular}


Table 4 shows the representation of jobs at which the respondents are employed in relation to their acquired qualification, where it can be found that the highest percentage of both groups of respondents performed tasks in the context of their acquired qualifications, but also differences in the performance of unskilled and assistant workers, and respondents who have completed secondary education. The obtained results indicate that $12.1 \%$ of deaf respondents, compared to $1.8 \%$ of workers without hearing impairment, educated for professions of opticians, painters, locksmiths, graphic artists, plumbers, bookbinders, tailors, photographers and central heating installers are engaged in jobs for which uneducated workers qualify for.

Deaf respondents performing the activities of assistant workers in $4.8 \%$ of cases, are educated for pro- fessions of tinsmiths, hairdressers, shoemakers and bookbinders, unlike respondents without hearing impairment which do not work as assistant workers. To similar results also came Johnson (1993), Welsh (1993) and Rosengreen (2007), which stated that much smaller selection of professions offered to deaf people in relation to people without hearing impairment in the course of their professional education, and they are often degraded at jobs which are not in accordance with their acquired qualifications. Ozdowski (2004) points out that although deaf people have a good knowledge and sufficient qualifications to perform certain tasks, they usually do not get the job for which they are qualified, and also Schroedel and Geyer (2000) state that $13 \%$ to $15 \%$ of deaf workers, covered by their research, have a higher level of education compared to the tasks they perform.

Table 4. Representation of jobs in relation to acquired qualification

\section{Workplace}

\begin{tabular}{lcccc} 
& $\mathbf{f}$ & $\mathbf{\%}$ & $\mathbf{f}$ & $\mathbf{\%}$ \\
\hline $\begin{array}{l}\text { Workplace in accordance with acquired qualification } \\
\begin{array}{l}\text { Workplace unqualified workers respondents with } \\
\text { secondary school education }\end{array}\end{array}$ & 102 & 82,2 & 106 & 95,5 \\
$\begin{array}{l}\text { Workplace assistant worker respondents with secondary } \\
\text { school education }\end{array}$ & 6 & 12,1 & 2 & 1,8 \\
$\begin{array}{l}\text { Workplace secondary school education respondents with } \\
\text { university degree }\end{array}$ & 1 & 4,8 & 0 & 0 \\
Total & 124 & 100 & 111 & 100 \\
\hline
\end{tabular}

The amount of respondents without hearing impairment respondents

,




\section{REFERENCES}

Benedict, B.S. \& Sass-Lehrer, M. (2007). Deaf and hearing partnerships: ethical and communication considerations. American Annals of the Deaf, 275-282.

Bullis, M., Bull, B., Johnson, B. \& Peters D. (1995). The schoolto-community transition experiences of hearing young adults and young adults who are deaf. Journal of Special Education, 28:405-423.

Bullis, M., Davis, C., Bull, B. \& Johnson, B. (1997). Expectations versus realities: Examination of the transition plans and experiences of adolescents who are deaf and adolescents who are hearing. Rehabilitation Counseling Bulletin, 40, 251-264.

Bujas, Z. (1968). Psihofiziologija rada. Zagreb: Škola narodnog zdravlja.

Boutin, D.L. \& Wilson, K.B. (2009). Professional jobs and hearing loss: A comparison of deaf and hard of hearing consumers. Journal of Rehabilitation, 75(1), 36-40.

Bonds, B. G. (2003). School-to-Work Experiences: Curriculum as a Bridge. American Annals of the Deaf, 38-48. Doi: 10.1353/aad.2003.0001

Capella, M. (2003). Comparing the occupational status of vocational rehabilitation consumers who are deaf or hard of hearing to the general labor force. JADARA, 36, 1-21. Doi/abs/10.1177/00343552030470010401

Danek, M.M. \& Busby, H. (1999). Transition planning and programming: Empowerment through partnership. Washington, DC: Gallaudet University.

DeCaro, J.J., Dowaliby, F.J. \& Maruggi, E.A. (1983). A crosscultural examination of parents' and teachers' expectations for deaf youth regarding careers. British Journal of Educational Psychology, 53, 358-363. Doi:10.1111/j.2044-8279.1983.tb02568.x

DeCaro, J.J., Mudgett-DeCaro, P.A. \& Dowaliby, F.J. (2001). Attitudes toward occupations for deaf youth in Sweden. American Annals of the Deaf, 146(1), 51. Doi: 10.1353/ aad.2012.0110

Gottshall, C. \& Stefanou, C. (2011). The Effects of On-going Consultation for Accommodating Students with Disabilities on Teacher Self-Efficacy and Learned Helplessness. Education, 321-331.

Jambor, E. \& Elliott, M. (2005). Self-esteem and Coping Strategies among Deaf Students. Journal of Deaf Studies and Deaf Education, 64-82. Doi: 10.1093/deafed/eni004

Jamieson, J.R., Zaidman-Zait, A. \& Poon, B. (2011). Family support needs as perceived by parents of preadolescents and adolescents who are deaf or hard of hearing. Deafness and Education International, 13, 110-130. Doi:10 .1179/1557069X11Y.000000005

Johnson, V.A. (1993). Factors impacting the job retention and advancement of workers who are deaf. Volta Review, 95, 341-356.
Lane, H., Hoffmeister, R. \& Bahan, B. (1996). A journey into the deaf-world. San Diego, CA: DawnSignPress.

Lent, R.W., Brown, S.D. \& Hackett, G. (2000). Contextual supports and barriers to career choice: A social cognitive analysis. Journal of Counseling Psychology, 47(1), 3649. Doi: 10.1037//0022-0167.47.1.36

Luft, P. \& Huff, K. (2011). How prepared are transition-age deaf and hard of hearing students for adult living? Results of the Transition Competence Battery. American Annals of the Deaf, 155(5), 569-579. Doi: 569-579 | 10.1353/ aad.2011.0000

Luft, P. (2014). A national survey of transition services for deaf and hard of hearing students. Career Development and Transition for Exceptional Individuals, 37(3), 177-192.

Ozdowski, S. (2004). Possible public inquiry on employment and disability. Australian Association of the deaf Inc.

Punch, R., Hyde, M. \& Creed P.A. (2004). Issues in the schoolto-work transition of hard of hearing adolescents. American Annals of the Deaf, 149. Doi: 10.1353/ aad.2004.0015

Punch, R., Creed, P. A. \& Hyde, M. (2006). Career barriers perceived by hard of hearing adolescents: A mixed methods analysis. Journal of Deaf Studies and Deaf Education, 11, 224-237. Doi: https://doi.org/10.1093/deafed/ enj023

Rosengreen, K. (2007). Understanding workplace expectations: a study of the perceptions of prelingually deaf workers and employers. Preuzeto sa: http://www.canberra.edu. $\mathrm{au} /$ researchrepository/items/c535e462-bb20-f49a-8ff78babaf263948/1/

Schildroth, A., Rawlings, B. \& Allen, T. (1991). Deaf students in transition: Education and employment issues for deaf adolescents. The Volta Review, 93(5), 41-53.

Schroedel, J.G. \& Carnahan, S.C. (1991). Parental involvement in career development. Journal of the American Deafness and Rehabilitation Association, 25.

Schroedel, J. (1992). Helping adolescents and young adults who are deaf make career decisions. The Volta Review, 3746.

Schroedel, J.G. \& Geyer, P.D. (2000). Long-term career attainments of deaf and hard of hearing college graduates: Results from a 15-year follow-up survey. American Annals of the Deaf, 145(4), 303-314. Doi: 10.1353/ aad.2012.0099

Weisel, A. \& Cinamon, G.C. (2005). Hearing, deaf, and hardofhearing Israeli adolescents' evaluation of deaf men and deaf women's occupational competence. Journal of Deaf Studies and Deaf Education, 10, 376-389. Doi:10.1093/deafed/eni045

Welsh, W.A. (1993). Factors influencing career mobility of deaf adults. Volta Review, 95, 329-339. 